\title{
Developing the Spouse Emotional Jealousy Scale*
}

\author{
Seval Kızıldağ ${ }^{1}$ \\ Adıyaman University
}

\author{
İbrahim Yıldırım² \\ Hacettepe University
}

\begin{abstract}
The Spouse Emotional Jealousy Scale (SEJS) has been developed in order to measure spousal jealousy levels of married individuals in the frame of this study. In the process of developing the SEJS, which is the aim of this study, data was gathered from married people living in Ankara. SPSS and LISREL 8.7 were used for data analysis. After exploratory factor analysis of 267 individual analyses, confirmatory factor analysis was carried out with data gathered from 303 individuals. The ensemble of the model's coefficients are $\left(\chi_{204}^{2}=600,988, p=.00, \chi^{2} / s d=2.95, G F I=.84, A G F I=.80, N F I=.87, C F I=.91, R M S E A=0.08\right)$. SEJS's reliability was tested on two separate sets of data: Firstly, Cronbach's alpha coefficient for the scale was found to be .95 in the analysis carried out on the set of data gathered from 267 individuals; this was also found to be .95 for the set of data gathered from 303 individuals. Secondly, the split half-test reliability was analyzed. The coefficient between the analyses of 267 individuals and 303 individuals was calculated as .93 for the one with 267 individuals and .92 for the one with 303 individuals. SEJS's validity and reliability show that the scale has the ability to measure spouses' levels of emotional jealousy validly and reliably.
\end{abstract}

\section{Keywords}

Jealousy $\bullet$ Emotional jealousy $\bullet$ Spouse emotional jealousy $\bullet$ Spouse emotional jealousy scale $\bullet$

Married people

\footnotetext{
" This article was produced as a part of corresponding author's doctoral thesis at Hacettepe University.

1 Correspondence to: Seval Kizıldağ (PhD), Faculty of Education, Adiyaman University, Adiyaman, Turkey. Email: sevalpdr@gmail.com

2 Faculty of Education, Hacettepe University, Ankara, Turkey. Email: iyil@hacettepe.edu.tr

Citation: Kızıldağ, S., \& Yıldırım, İ. (2017). Developing Spouse Emotional Jealousy Scale. Educational Sciences: Theory \& Practice, 17, 175-190. http://dx.doi.org/10.12738/estp.2017.1.2441
} 
Romantic jealousy is conceptualized as the complicated feelings, ideas, and behaviors that include threats to one's self-worth or self-relation (White, 1981). This concept is mostly stated in the literature as the perceived threat of losing a precious relationship or of its deterioration (Altınmakas, 2011; Buss, Larsen, Westen, \& Semmelroth, 1992; Clanton, 1981; Edalati \& Redzuan, 2010; Pines \& Friedman, 1998). When analyzing the performed studies, the concept of romantic jealousy is generally seen to have a negative connotation (Clanton \& Lynn, 1977; Marelich, 2002; Pines, 1992). Within the dynamics of this concept lays a decrease of love within the marriage, resentment from the spouse, fear of the relationship getting worn out, anxiety, and/or emotions of self-worthlessness. Wreen (1989) states that at the center of romantic jealousy could be a lack of confidence, the fear of losing one's spouse, or emotional coldness, in particular. An individual who suffers from romantic jealousy can simultaneously experience emotions such as anger, unhappiness, and fear (Sharpseteen, 1991). This negative aspect of romantic jealousy may cause aggression and violence, and lead to divorce for some individuals. Additionally, romantic jealousy is noticed as an important possible reason of unhappiness and trouble for spouses, as well as being among the primary causes of divorce in unhappy marriages, domestic violence, and murdered spouses (Daly, Wilson, \& Weghorst, 1982; Pines \& Friedman, 1998). Freud states that jealousy is a universal emotion, as well as a trauma concealed during an individual's negative childhood and revived again in adulthood (Pines, 1992). In addition to this, Sullivan states that jealousy is an unpleasant emotion that may cause a deep feeling of inadequacy (Mathes, 1992); according to the theory of evolution, jealousy is an instinct with the aim of protecting relationships (Kenrick \& Trost, 1997). According to transactional analysis, jealousy, values, beliefs, expectations, antecedents, and personality traits are formed through their relation with one's social environment (Bringle, 1995). Additionally, there are other approaches in the literature like the double-strike approach (DeSteno \& Salovey, 1996; Harris, 2003), which refers to the difference between men and women in terms of the situation-specific ability of reasoning the explanation of romantic jealousy. This is akin to the strength-differentials approach, which states that men and women have different types of jealousy because of the strength differences between the two genders, not because of evolution, however, these strength differences are based on their self-esteem because men are more stronger than women about selfesteem (Mead \& White, 1981, pp. 300-309 as cited in Demirtaş-Madran, 2008).

According to the evolutionary theory, men and women have basic differences between them in terms of jealousy (DeSteno, Bartlett, \& Salovey, 2002). These are divided into two categories, sexual jealousy and emotional jealousy; the evolutionary theory defines sexual jealousy as a jealousy which occurs as a result of an individual knowing or suspecting that their spouse is having an affair with someone else. Emotional jealousy occurs as a result of one knowing or suspecting that their spouse 
is emotionally attached to someone else (Demirtaş-Madran, 2008). In the literature, a number of studies have indicated that these two types of jealousy are experienced in different ways by men and women. Men experience more sexual jealousy while women experience emotional jealousy more (Edalati \& Redzuan, 2010; Fussell, 2012; Varga, Gee, \& Munro, 2011; Ward \& Voracek, 2004). Shackelford and Buss (1997) designated seven behaviors that arouse emotional jealousy: a) relational dissatisfaction or loss of love (i.e., spouses who say they want to date other people); b) emotional neglect (i.e., spouses who forget special days or who stop expressing their love); c) unwillingness to spend time together (i.e., spouses who stop inviting their partner to friendly gatherings); d) passive rejection or showing inconsiderate behaviors (i.e., being rude, less loving, less respectful); e) communicating angrily, critically, or suspiciously (i.e. spouses who often make non-constructive criticism or try to start fights); f) avoiding talking about a specific person (this is said to cause the suspicion that there is an affair between the spouse and that person); and g) adopting guilt-ridden or anxious communication styles (behaving over-anxious, or over-tolerant and forgiving). The Spouse Emotional Jealousy Scale, developed in this study, has been improved based on the qualities of the jealousy concept as explained by Shackelford and Buss (1997). Like many cultures, Turkish culture's concept of romantic jealousy is also affected by cultural relations and affiliated dynamics. As seen in the saying, "The loving spouse is a jealous one," sometimes romantic jealousy is an affirmed and well-accepted fact; however, sometimes it may not be expressed easily in monogamous societies in which sexual issues are perceived as relatively taboo. Considering the difficulties of even expressing the concept of romantic jealousy, this concept was examined in the scope of this study based on Shackelford and Buss's viewpoints dealing with the emotional aspect of jealousy.

A number of studies dealing with variations of romantic jealousy occur in the literature. Some research this in positive terms within variants such as traditional sexual roles and romantic love (Hansen, 1982; Nagra, 2004), relational apathy (Hansen, 1985), feelings of insecurity and protectiveness (White, 1981), when attempting to socialize with the opposite sex (Marelich, 2002), and in negative terms with self-esteem and trust (Hansen, 1985). In research carried out in terms of demographics (age, gender, marital status, birth order, etc.), older women are observed to be emotionally jealous of their husbands, while young women are sexually jealous of their husbands (Shackelford, Voracek, Schmitt, Buss, WeekesShackelford \& Michalski, 2004), that single women are more jealous than married women and married women are more jealous than married men (Demirtaş, 2004), and that middle and younger children are more jealous than older ones (McGuirk \& Pettijohn, 2008). In addition, individuals who have a long-distance relationship have been observed to show no difference in jealousy compared with individuals whose relationships are geographically close (Timmerman, 2001). Women who get 
married after flirting/dating are also seen to have more jealousy than women who have arranged marriages; jealousy decreases the satisfaction of marriage in men who marry after dating, but increases this satisfaction in men whose marriage was arranged (Güngör-Houser, 2009).

There is a strong relationship between aggressiveness and jealousy (loss of love, refusal, distrust, fear, loss of self-confidence and emotional support, and decreased feeling of being special; (Edalati \& Redzuan, 2010; Warber, 2007). Romantic jealousy is related to situations like obsession (Carson \& Cupach, 2000), attachment anxiety (Guerrero, 1998), relational dissatisfaction (Guerrero \& Eloy, 1992), and verbal/physical abuse (Barnett, Martinez, \& Bluestein, 1995, pp. 243-251 as cited in Elphinston, Feeney, \& Noller, 2011).

In Turkey, limited studies are available on the use of romantic jealousy scales. These scales are developed in other cultures and adapted for Turkish culture (Curun \& Çapkın, 2014; Demirtaş, 2004; Güngör-Houser, 2009; Karakurt, 2001). One scale that measures romantic jealousy is the multi-dimensional jealousy scale. This scale was developed by Pfeiffer and Wong (1987) and adapted to Turkish by Karakurt (2001); it measures cognitive, emotional, and behavioral reactions that occur in situations of jealousy. Another scale that measures romantic jealousy is the romantic jealousy scale developed by Pines and Aronson (1983), and adapted for Turkish by Demirtaş (2004). This scale consists of five factors: jealousy triggers, jealous reactions, ways to compete with jealousy, the effects of jealousy, and reasons for jealousy. Although romantic jealousy is a universal emotion that occurs in close relationships in almost every culture, it also includes essential cultural elements and life styles (Buunk, Angleitner, Oubaid, \& Buss, 1996; Edalati \& Redzuan, 2010; Morales Padilla, 2007; Speed \& Gangstead, 1997). However, the universal content of romantic jealousy is simply not isolated from cultural elements; therefore, it is necessary and important to measure romantic jealousy with a scale developed for that culture. When the aspects of relevant scales were examined, the general aspects of the concept of romantic jealousy are seen to be discussed. However, in the scope of this study, the concept of romantic jealousy has been discussed within the aspect of marital relations and emotional jealousy. From this point of view, the SEJS was developed with the aim of measuring the emotional jealousy of married individuals in Turkish culture.

\section{Method}

\section{Study Group}

In the process of developing the SEJS, data was gathered from four different groups consisting of married individuals living in Ankara. In this study, the convenience sampling method was chosen from among the non-random sampling methods. The 
criterion for individuals to be in the study group is being married. This criterion is based on the assumption that emotional jealousy can occur only in emotion-based relations between romantically involved individuals. Demographic information regarding the first and second study groups are presented in Table 1, and demographic information regarding the third and fourth study groups are presented in Table 2.

Table 1

Demographic Information Regarding the First and Second Study Groups

\begin{tabular}{|c|c|c|c|c|c|}
\hline & & \multicolumn{2}{|c|}{ First Group } & \multicolumn{2}{|c|}{ Second Group } \\
\hline Variable & & $f$ & $\%$ & $f$ & $\%$ \\
\hline \multirow{4}{*}{ Gender } & Women & 6 & 60.0 & 24 & 73.0 \\
\hline & Men & 4 & 40.0 & 9 & 27.0 \\
\hline & Average of age & \multicolumn{2}{|c|}{35} & \multicolumn{2}{|c|}{32} \\
\hline & Total & 10 & 100.0 & 33 & 100 \\
\hline
\end{tabular}

When Table 1 is examined, this group consists of 10 married individuals in order to form the Scale's item pool. Six $(60 \%)$ of these individuals are female and four $(40 \%)$ of them are male; their average age is 35 . This group consisted of thirty-three $(100 \%)$ married, employed individuals who were contacted in order to make the pilot study of the scale. Twenty-four (73\%) of these individuals are female and nine (27\%) are male, with a collective average age of 32 .

Table 2

Demographic Information Regarding the Third and Fourth Study Group

\begin{tabular}{|c|c|c|c|c|c|}
\hline \multirow[b]{2}{*}{ Variables } & & \multicolumn{2}{|c|}{ Third Group } & \multicolumn{2}{|c|}{ Fourth Group } \\
\hline & & $\mathrm{f}$ & $\%$ & $\mathrm{~F}$ & $\%$ \\
\hline \multirow{3}{*}{ Sex } & Women & 130 & 48.70 & 133 & 44.5 \\
\hline & Men & 137 & 51.30 & 170 & 55.5 \\
\hline & High School & 39 & 14.40 & 45 & 14.6 \\
\hline \multirow[t]{2}{*}{ Education level } & College/university & 207 & 77.90 & 231 & 76.6 \\
\hline & Graduate & 21 & 7.70 & 27 & 8.8 \\
\hline \multirow{2}{*}{$\begin{array}{l}\text { Number of } \\
\text { marriages }\end{array}$} & First Marriage & 252 & 94.50 & 289 & 95.5 \\
\hline & Second Marriage & 15 & 5.50 & 14 & 4.5 \\
\hline \multirow{4}{*}{ Marriage Style } & Arranged Marriage & 101 & 38.70 & 123 & 39.9 \\
\hline & Romantic & 166 & 61.30 & 180 & 60.1 \\
\hline & Average age & \multicolumn{2}{|c|}{39} & \multicolumn{2}{|c|}{40} \\
\hline & Total & 267 & 100.0 & 303 & 100 \\
\hline
\end{tabular}

When Table 2 is examined, the 267 married individuals who were contacted for explanatory factor analysis in order to test the construct validity of the scale are seen to be $130(48.7 \%)$ women and $137(51.3 \%)$ men, with a collective average age of 39 . In addition, 39 (14.4\%) people from the third study group have a high school-level education, 207 (77.9\%) have a college/university-level education, and $21(7.7 \%)$ have a postgraduate-level education. At the same time, 252 (94.5\%) of these individuals are seen to have been married once, and $15(5.5 \%)$ of them have been married twice; $101(38.7 \%)$ of these marriages are arranged marriages, and $166(61.3 \%)$ of them resulted from dating. From the fourth study group, when the demographic features of 
the 303 married individuals contacted for confirmatory factor analysis of the scale are examined in Table 2, 133 (44.5\%) of these individuals are seen to be women and 170 (55.5\%) to be men; their average age is 40 . Additionally, 45 (14.6\%) individuals from the fourth study group have a high school-level education, 231 (76.6\%) have a college/ university-level education, and $27(8.8 \%)$ have a postgraduate-level education. At the same time, 289 (95.5\%) of these individuals are seen to have married once, and 14 (4.5\%) of them to have married twice; 123 (39.9\%) of these marriages are arranged marriages and $180(60.1 \%)$ are a result of dating.

\section{Analysis Method}

First, the related literature was analyzed in order to develop the SEJS. In the related literature, scale items were written by using the dimensions of the concept of emotional jealousy as defined by Shackelford and Buss (1997). At the same time, interviews were carried out with 10 married individuals in order to compose the scale's item pool. These people were asked, "When are you jealous of your spouse or partner?" After discussions on the literature and with the individuals, an item pool of 44 items was prepared to be presented for expert opinion. A standard number of between five and seven experts were consulted about the items in the item pool (Lester \& Bishop, 2000). After the items were re-examined as statements, they were arranged in the form of a scale and the form, consisting of 44 items, was presented to academic members from different universities to get their opinions. Six of these members work in the Counseling, and four work in Assessment and Evaluation. The experts were requested to sign off on items as being appropriate, inappropriate, or needing correction. The consulted experts found $90 \%$ of the items to be appropriate. These items were brought into the scale unchanged (Büyüköztürk, 2010). Items that needed to be corrected were changed, and items that were deemed inappropriate were removed from the scale form. After addressing the experts' opinions, the 33-item scale was chosen to be a Likert-type, 3-point scale ( $\mathrm{I}$ am too jealous $=3$; I am a little jealous $=2$; I am never jealous $=1$ ). The test form of the 33-item scale was applied to 33 people. After the test application, necessary corrections were made to the SEJS and, per the benchmark of item-comprehensibility, it was decided that the final form of the scale should have 30 items.

\section{Analysis}

SPSS 17.00 and LISREL 8.7 were used for data analysis. Exploratory factor analysis was carried out on the data for SEJS's validity study. Whether the data are appropriate for the factor analysis or not was examined through the Kaiser-MeyerOlkin (KMO) parameter and the Bartlett sphericity test. As the item scores are ranked between 1 and 3, the method for obtaining the principal axis in exploratory factor 
analysis (Fabrigar, Wegener, MacCallum, \& Strahan, 1999) was realized by using the Oblimin axis-rotation technique. After exploratory factor analysis, confirmatory factor analysis was carried out on a different data set, and the factors obtained and relations between them were analyzed. Cronbach's alpha coefficient was calculated for the scale's reliability.

\section{Findings}

Content and then structural concept validity were analyzed in the validity studies of the SEJS. Cronbach's alpha of internal consistency was measured in the reliability study.

\section{Validity}

The SEJS validity studies were carried out in two ways. First, the scale's content validity was analyzed. Experts' opinions were consulted on content validity, and in consideration of the feedback from the experts, a 33-item form was attained by removing 11 items from the original 44-item form (i.e., my spouse is more social than me, my spouse is more attractive than me, and my spouse makes jokes with the opposite sex). Due to the rearrangements, a 30-item test form was attained. SEJS's structural concept validity was analyzed next. For this, exploratory factor analysis was carried out, followed by confirmatory factor analysis.

Exploratory Factor Analysis (EFA). The data gathered from 267 married individuals were used for SEJS's EFA. These were analyzed using the KaiserMeyer-Olkin (KMO) parameter and Bartlett sphericity test in terms of the data's appropriateness for factor analysis. The KMO value was found to be .940 , and the Bartlett sphericity test found values of $x^{2}=4312.785, S D=231$, and $p=.00$. These parameters are considered to be appropriate for factor analysis because the KMO value is greater than .60 and the Bartlett test shows significance as per the benchmark (Büyüköztürk, 2010) of the relation between items. 


\section{Scree Plot}

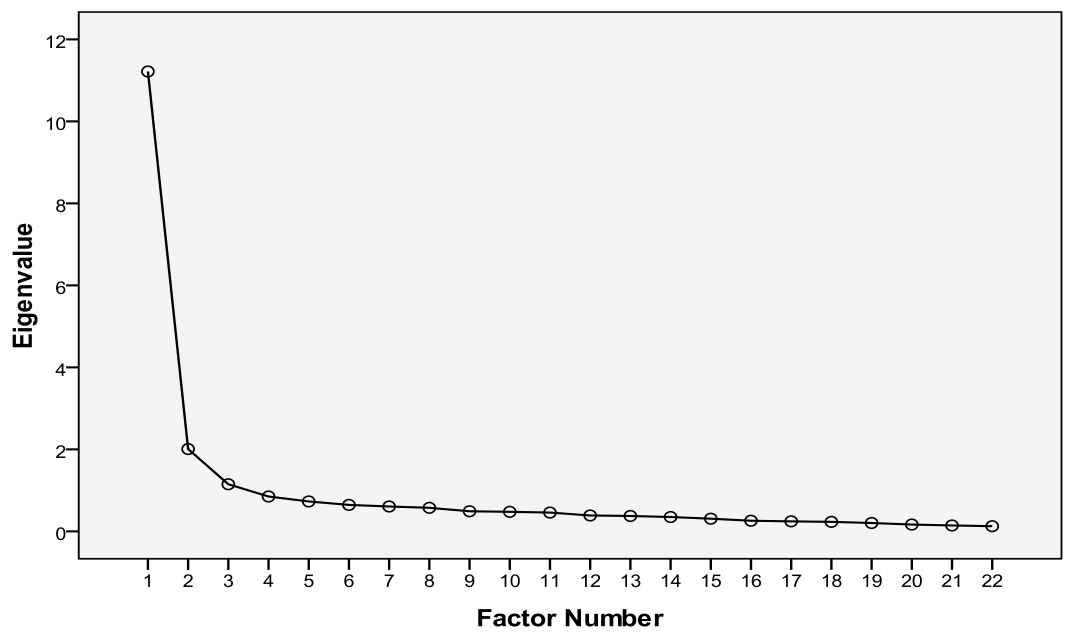

Figure 1. Scree plot.

The scree plot given in Figure 1 resulted from the analysis for obtaining principal axis factors without restriction on the number of dimensions. After reviewing the scree plot, the scale is seen to have a three-factor form. According to the table of explained total variance, the first variance explains $49.25 \%$ of the total variance; two factors together explain $56.70 \%$ of the total variance and the three factors together explain $59.75 \%$ of the total variance. The criterion was designated that significant loadings should be greater than .30 in their own dimension and less than .25 in other dimensions in determining item-factor correlations (loading), in consideration of not only the number of items in the scale but also the number of individuals in the sample (Hair, Black, Babin \& Anderson 2010; Raunberheim, 2004; Stevens, 2009; Tabachnick \& Fidell, 2007).

As seen in Table 3, the item-factor load values varied between .91 and .49 for the first factor, between .91 and .41 for the second factor, and between .56 and .49 for the third factor. There are 11 items in the first factor, eight items in the second factor, and three items in the third factor. In the end, the scale was found to consist of three factors and 22 items. The factors were named by analyzing the content of items in each factor. Accordingly, the first SEJS factor is feeling unworthy, the second factor is relationship dissatisfaction and lack of love, and the third factor is unwillingness to spend time together. The first and second factors were named similarly due to the close similarities from the list of seven behaviors determined by Shackelford and Buss (1997) that stimulate emotional jealousy; the third factor was named parallel with the literature on romantic jealousy in terms of item-content. 


\begin{tabular}{|c|c|c|c|}
\hline & \multicolumn{3}{|c|}{ Factors } \\
\hline & Feeling Unworthy & $\begin{array}{c}\text { Relationship } \\
\text { Dissatisfaction And Lack } \\
\text { of Love }\end{array}$ & $\begin{array}{l}\text { Unwillingness To Spend } \\
\text { Time Together }\end{array}$ \\
\hline \multicolumn{4}{|l|}{ Items } \\
\hline 24 & 0.907 & & \\
\hline 23 & 0.834 & & \\
\hline 30 & 0.823 & & \\
\hline 21 & 0.815 & & \\
\hline 27 & 0.786 & & \\
\hline 28 & 0.765 & & \\
\hline 20 & 0.721 & & \\
\hline 26 & 0.707 & & \\
\hline 22 & 0.695 & & \\
\hline 25 & 0.683 & & \\
\hline 19 & 0.492 & & \\
\hline 6 & & 0.913 & \\
\hline 5 & & 0.824 & \\
\hline 4 & & 0.615 & \\
\hline 7 & & 0.593 & \\
\hline 8 & & 0.571 & \\
\hline 1 & & 0.523 & \\
\hline 3 & & 0.506 & \\
\hline 9 & & 0.405 & \\
\hline 11 & & & 0.564 \\
\hline 14 & & & 0.534 \\
\hline 12 & & & 0.490 \\
\hline
\end{tabular}

Confirmatory Factor Analysis (CFA). CFA was carried out using the program LISREL 8.7 on the three-factor structure in order to analyze SEJS's validity. CFA applied on SEJS's test model was performed over a different set of data gathered from 303 individuals. Because of the convenience of performing CFA on a different sampling than the EFA(Fabrigar et al., 1999), CFA and EFA were realized over the data obtained from different study groups within the scope of this study. The hypothesis tested that model-identifying items would be represented with three factors, and that 11 items would occur in the feeling unworthy, eight items in the dissatisfaction and lack of love, and 3 items in the unwillingness to spend time together factors. 


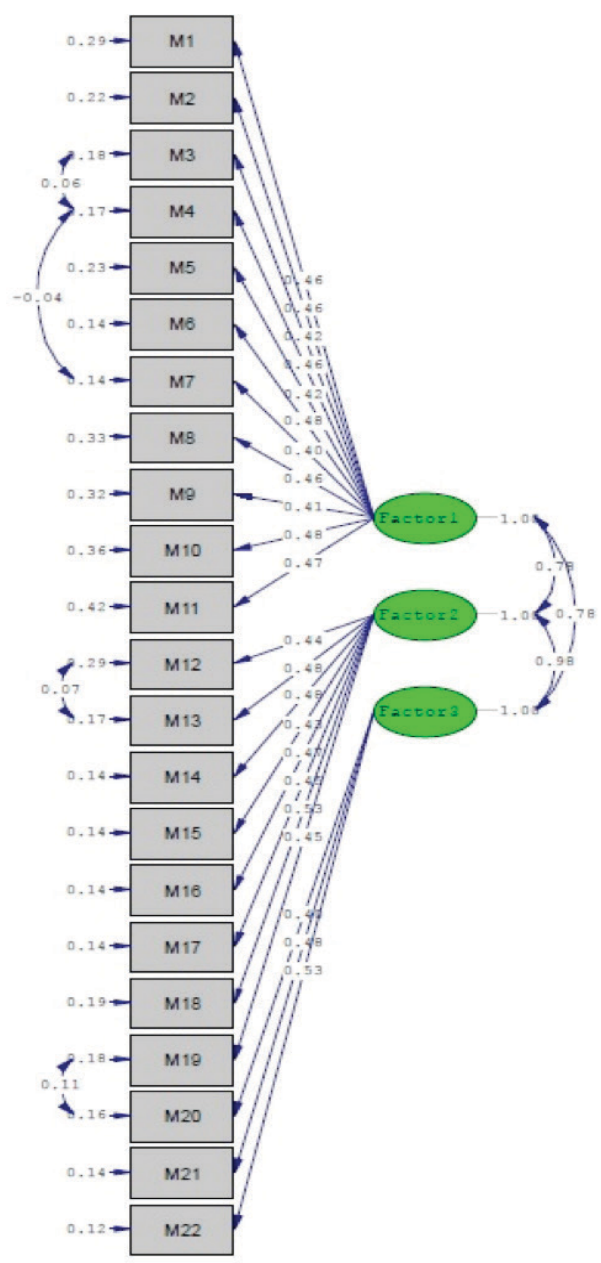

Figure 2. CFA carried out with data gathered from the SEJS's 4th study group.

When analyzing the relationships between the factors' items, item-factor loadings for feeling unworthy vary between $.64 \leq \lambda \leq .83$; item-factor loadings for relational dissatisfaction and lack of love vary between $.60 \leq \lambda \leq .78$; and item-factor loadings for unwillingness to spend time together vary between $.67 \leq \lambda \leq .71$. Additionally, the general adaptability parameters for the evaluation model are $\chi_{204}^{2}=600,988$ and $p=$ $.00\left(\chi^{2} / s d=2.95, G F I=.84, A G F I=.80, N F I=.87, C F I=.91\right.$, RMSEA $\left.=0.08\right)$. In general, model fit parameters are presented below in Table 4 (Schermelleh-Engel \& Moosbrugger, 2003). In this case, the obtained values of factor loadings and items show the model to be acceptable. 
Table 4

Model-Fit Parameters

\begin{tabular}{ccc}
\hline Fit Indices & Good Fit & Sufficient Fit \\
\hline$\left(\chi^{2} / \mathrm{d} f\right)$ & $0 \leq\left(\chi^{2} / d f\right) \leq 2$ & $2 \leq\left(\chi^{2} / d f\right) \leq 3$ \\
$p$ value & $0.05<\mathrm{p} \leq 1.00$ & $0.01 \leq \mathrm{p} \leq 0.05$ \\
$R M S E A$ & $0 \leq R M S E A \leq 0.05$ & $0.05 \leq R M S E A \leq 0.10$ \\
$N F I$ & $0.95 \leq N F I \leq 1.00$ & $0.90 \leq N F I \leq 0.95$ \\
$C F I$ & $0.95 \leq C F I \leq 1.00$ & $0.90 \leq C F I \leq 0.95$ \\
$G F I$ & $0.95 \leq G F I \leq 1.00$ & $0.90 \leq G F I \leq 0.95$ \\
$A G F I$ & $0.90 \leq A G F I \leq 1.00$ & $0.85 \leq A G F I \leq 0.90$
\end{tabular}

\section{Findings on Reliability Studies}

SEJS's reliability was tested on two separate sets of data. SEJS's Cronbach's alpha coefficient for the first was found to be 0.951 in the analysis carried out on the set of data gathered from 267 individuals; Cronbach's alpha was found to be 0.947 in the analysis carried out on the set of data gathered from 303 individuals. Two separate reliability tests were analyzed. The reliability coefficient comparing the analyses of 267 individuals and 303 individuals was calculated. SEJS's items were separated into two halves; the coefficients were calculated as 0.925 for the one with 267 individuals and 0.922 for the one with 303 individuals. A reliability coefficient of .70 or more calculated for a psychology test is generally considered efficient for the reliability of test scores (Büyüköztürk, 2010). Accordingly, the reliability coefficients that were obtained show that SEJS has the ability to measure spouses' levels of emotional jealousy reliably. Thus the analysis was concluded with the split-half test of reliability.

\section{Discussion}

Related literature was first analyzed in order to develop the Spouse Emotional Jealousy Scale (SEJS). From the related literature, scale items were listed by using the dimensions of the concept of emotional jealousy as defined by Shackelford and Buss (1997). At the same time, interviews were carried out with 10 married individuals (i.e., in an emotional relationship) in order to compose the item-pool for the scale; they were asked, "When are you jealous of your spouse or partner?" After reviewing the literature and interviewing the individuals, an item-pool of 44 items was arranged to present to expert opinion. The test-form application of the scale, which had 33 items after the expert-opinion review, was applied to 33 married people. While considering their relationships, individuals stated their jealousness by choosing an option of "This reflects me a lot," "This somewhat reflects me," or "This doesn't reflect me at all" for each of the 33 items on the scale. After the test application, per the benchmark of item comprehensibility, three more items were removed from the scale and the scale's final form was determined to consist of 30 items. 
Exploratory factor analysis was carried out for the structural validity of the SEJS. The EFA results showed that the items from the SEJS explained $59.75 \%$ of the total variance and were gathered under three dimensions. The item-variance explanation for SEJS's structure through three dimensions can be declared to be high and within acceptable limits. The scale's factor loading values varied between .91 and .49 , between .91 and .41 , and between .56 and .49 for the first, second, and third factors respectively. This shows the scale's item-factor loading is acceptable.

As a result of the EFA, the scale was determined to consist of 22 items. This is considered to ideal for adults. After the items were distributed intro three subdimensions from the EFA, the items' sub-dimensions were able to be related to feeling unworthy, relational dissatisfaction and lack of love, and unwillingness to spend time together in the marriage. The items in the first dimension were thus called because they consist of negative items, such as one feeling unworthy towards their spouse or a sense of apathy between the two. Example items from this sub-dimension can be shown, such as "While my spouse tolerates what someone else of the opposite sex does, they criticize me for doing the same thing," and "My spouse says I am awkward and unsuccessful by comparing me with someone else of my gender." The items in the second sub-dimension were titled relationship dissatisfaction and lack of love due to the apathy one feels from their spouse. Examples of items in this dimension are "My spouse flirts with others besides me" and "My spouse interferes in my relations with the opposite sex." The items in the third sub-dimension are called unwillingness to spend time together because they represent the reluctance to spend time together within the marriage. The items in this dimension can be exemplified with "My spouse prefers spending time with others rather than with me" and "My spouse spends time with friends whenever possible." Additionally, each item in the scale's dimension is theoretically appropriate for total score. A higher score on the scale indicates the spouse has high jealousy levels in their relationship. There is a scoring gap received from the scale between scores of 22 and 66. The scale's items are scored as follows: $1=\mathrm{I}$ am never jealous (this doesn't reflect me at all), 2 = I am jealous sometimes (this somewhat reflects me), and $3=\mathrm{I}$ am jealous a lot (this reflects me a lot). After the exploratory factor analysis, confirmatory factor analysis was carried out with data gathered from 303 individuals, and fairly good cohesion indices were obtained from the scale. The general cohesion coefficients of the evaluation model are $\chi_{204}^{2}=$ $600,988, p=.00 ; \chi^{2} / s d=2.95, G F I=.84, A G F I=.80, N F I=.87, C F I=.91, R M S E A$ $=0.08$. A $G F I>.90$ shows good cohesion, an $A G F I>.95$ shows perfect cohesion, an $N F I>.90$ shows good cohesion, a $C F I>.90$ shows good cohesion, and an RMSEA $<.05$ shows perfect cohesion (Çokluk, Şekercioğlu, \& Büyüköztürk, 2010). In this case, the demonstrated values of the obtained factor loadings show the model to be acceptable. 
The scale's coefficients of internal consistency were calculated using a total of 267 data gathered from the third study group and subjected to exploratory factor analysis, and through a total of 303 data subjected to confirmatory factor analysis. Cronbach's alpha coefficients obtained from SEJS's third study group were found to be .95 for the first sub-dimension, feeling unworthy; .89 for the second sub-dimension, relationship dissatisfaction and lack of love; and .74 for the third sub-dimension, unwillingness to spend time together. Cronbach's alpha internal consistency coefficients on data gathered from SEJS's fourth group from data obtained over 303 individuals and subjected to confirmatory factor analysis were found to be .94 for the first subdimension, .89 for the second sub-dimension, and .72 for the third sub-dimension. The coefficients obtained from SEJS's sub-dimensions show that the scale is sufficiently reliable.

The evidence obtained from SEJS's validity and reliability analyses shows SEJS' ability to measure spouses' levels of emotional jealousy validly and reliably. Counselors in the field of Marriage and Family Counseling can determine couples' levels of jealousy and plan research using the SEJS. In this way, at-risk married individuals can be identified and presented with marriage counseling services. Researchers who work in the fields of couples and marriage counseling can use this scale in scientific or descriptive studies. Based on the assumption that emotional jealousy can occur intrinsically in all romantic relationships, new forms of this scale involving those in arranged marriages or those who married after dating their spouse can be created. While the Spouse Emotional Jealousy Scale was being developed, the emotional aspect of romantic jealousy was discussed. In future researches, jealousy scales that discuss other aspects of romantic jealousy, such as sexual jealousy, can be developed. The concept of a spouse's emotional jealousy is related with cultural and social values. For this reason, the SEJS can be re-tested on groups with different socio-cultural features (i.e., low, middle, or high socioeconomic level, etc.).

\section{References}

Altınmakas, B. (2011). Kıskançlık kavramının psikolojideki yeri [The place of the concept of jealousy in psychology]. Eğitimde Yansımalar, 29, 22-24.

Bringle, R. G. (1995). Sexual jealousy in the relationships of homosexual and heterosexual men: 1980 and 1992. Personal Relationships, 2, 313-325. http://dx.doi.org/10.1111/j.1475-6811.1995. tb00095.x

Buss, D. M., Larsen, R. J., Westen, D., \& Semmelroth, J. (1992). Sex differences in jealousy: Evolution, physiology and psychology. Psychological Science, 3(4), 251-255. http://dx.doi. org/10.1111/j.1467-9280.1992.tb00038.x

Buunk, B. P., Angleitner, A., Oubaid, V., \& Buss, D. M. (1996). Sex differences in jealousy in evolutionary and cultural perspective: Tests from the Netherlands, Germany, and the United States. Psychological Science, 7(6), 359-379. http://dx.doi: 10.1111/j.1467-9280.1996.tb00389.x 
Büyüköztürk, Ş. (2010). Sosyal bilimler için veri analizi el kitabı [Data analysis handbook for the social sciences]. (11th ed.). Ankara, Turkey: Pegem Akademi.

Clanton, G. (1981). Frontiers of jealousy research: Introduction to the special issue on jealousy. Alternative Lifestyles, 4, 259-273.

Clanton, G., \& Lynn, S. ( 1977). Jealousy. Englewood Cliffs, NJ: Prentice-Hall.

Çokluk, Ö., Şekercioğlu, G., \& Büyüköztürk, Ş. (2010). Sosyal bilimler için çok değişkenli istatistik: SPSS ve LISREL uygulamalarl [Highly variable statistics for the social sciences: SPSS and LISREL applications]. Ankara, Turkey: Pegem Akademi.

Curun, F., \& Çapkın, M. (2014). Romantik kıskançlığın bağlanma stilleri, benlik saygısı, kişilik özellikleri ve evlilik doyumu açısından yordanması [Predicting romantic jealousy attachment styles in terms of self-esteem, personality characteristics, and marriage satisfaction]. Psikoloji Çalışmaları Dergisi, 34(1), 1-22.

Daly, M., Wilson, M., \& Weghorst, S. J. (1982). Male sexual jealousy. Ethology and Sociobiology, 3, 11-27. http://dx.doi.org/10.1016/0162-3095(82)90027-9

Demirtaş, A. (2004). Yakın ilişkilerde kıskançlık (bireysel, ilişkisel ve durumsal değişkenler) [Jealousy (individual, relational, and situational) in close relationships] (Doctoral dissertation, Ankara University, Ankara, Turkey). Retrieved from https://tez.yok.gov.tr/UlusalTezMerkezi/

Demirtaş-Madran, A. (2008). Duygusal ve cinsel kıskançlık açısından temel cinsiyet farklılıkları: Evrimsel yaklaşım ve süregelen tartışmalar [Basic gender differences in terms of emotional and sexual jealousy: The evolutionary approach and ongoing debates]. Türk Psikiyatri Dergisi, 19(3), 300-309.

DeSteno, D. A., \& Salovey, P. (1996). Evolutionary origins of sex differences in jealousy? Questioning the "fitness" of the model. Psychological Science, 7, 367-372. http://dx.doi: 10.1111/j.1467-9280.1996.tb00391.x

DeSteno, D., Bartlett, M. Y., \& Salovey, P. (2002). Sex differences in jealousy: Evolutionary mechanism or artifact of measurement? Journal of Personality and Social Psychology, 83(5), 1103-1116. http://dx.doi.org/10.1037//0022-3514.83.5.1103

Edalati, A., \& Redzuan, M. (2010). The relationship between jealousy and agression: A review of literatures related to wives' aggression. European Journal of Scientific Research, 39(4), 498-504.

Elphinston, R. A., Feeney, J. A., \& Noller, P. (2011). Measuring romantic jealousy: Validation of the multidimensional jealousy scale in Australian samples. Australian Journal of Psychology, 63, 243-251. http://dx.doi.org/10.1111/j.1742-9536.2011.00026.x

Fabrigar, L. R., Wegener, D. T., MacCallum, R. C., \& Strahan, E. J. (1999). Evaluating the use of exploratory factor analysis in psychological research. Psychological Methods, 4(3), 272-299. http://dx.doi.org/10.1037/1082-989X.4.3.272

Fussell, N. J. (2012). Between-sex differences in romantic jealousy: Substance or spin? A qualitative analysis. Evolutionary Psychology, 10(1), 136-172. http://dx.doi.org/10.1177/ 147470491201000114

Güngör-Houser, A. (2009). Evli bireylerin sahip oldukları iletişim çatışması türü, romantik kıskançlık ve duygusal zeka düzeylerinin evlilik doyumlarl üzerine etkisi [The effect of the type of verbal conflict with one's spouse and the levels of romantic jealousy and emotional intelligence on marital satisfaction] (Doctoral dissertation, Ankara University, Ankara, Turkey). Retrieved from https://tez.yok.gov.tr/UlusalTezMerkezi/ 
Hair, J. F., Black, W. C., Babin, B. J., \& Anderson, R. E. (2010). Multivariate data analysis. New York, NY: Pearson Company.

Hansen, G. L. (1982). Reactions to hypothetical, jealousy producing events. Family Relations, $31(4), 513-518$.

Hansen, G. L. (1985). Perceived threats and marital jealousy. Social Psychology Quarterly, 48(3), 262-268. http://dx.doi.org/10.2307/3033686.

Harris, C. R. (2003). A review of sex differences in sexual jealousy, including self-report data, psychophysiological responses, interpersonal violence and morbid jealousy. Personality and SocialPsychologyReview, 7, 102-128.http://dx.doi.org/10.1207/S15327957PSPR0702_102-128

Karakurt, G. (2001). The impact of adult attachment styles on romantic jealousy (Master's thesis, Middle East Technical University, Ankara, Turkey). Retrieved from https://tez.yok.gov.tr/ UlusalTezMerkezi/

Kenrick, D. T., \& Trost, M. R. (1997) Evolutionary approaches to relationships. In S. Duck (Ed), Handbook of personal relationships: Theory, research and interventions, (pp. 160-175). Chichester, UK: John Wiley \& Sons.

Lester, P. E., \& Bishop, L. K. (2000). Handbook of tests and measurement in education and the social sciences. Lanham, MD: Scarecrow Press.

Marelich, W. D. (2002). Effects of behavior settings, extradyadic, behaviors, and interloper characteristics on romantic jealousy. Social Behavior and Personality, 30(8), 785-794. http:// dx.doi.org/10.2224/sbp.2002.30.8.785

Mathes, E. W. (1992). Jealousy: The psychological data. Lanham, MD: University Press of America.

McGuirk, E. M., \& Pettijohn, T. F., II. (2008). Birth order and romantic relationship styles and attitudes in college students. North American Journal of Psychology, 10(1), 37-52. http://dx.doi. org/10.1093/acprof:oso/9780195372090.001.0001

Morales Padilla, L. (2007). Romantic jealousy as a function of culture and gender (Master's thesis). Available from ProOuest Dissertations and Theses database. (UMI No. 1445331)

Nagra, S. (2004). Jealousy in romantic relationship: The effects of manipulating self-esteem (Master's thesis). Available from ProQuest Dissertations and Theses database. (UMI No. MQ87698)

Pfeiffer, S. M., \& Wong, P. T. P. (1987). Multidimensional jealousy. Journal of Social and Personal Relationships, 6, 181-196. http://dx.doi.org/10.1177/026540758900600203

Pines, A. M. (1992). Romantic jealousy: Understanding and conquering the shadow of love. New York, NY: St. Martin's Press.

Pines, A. M., \& Aronson, E. (1983). Antecedents, correlates and consequences of sexual jealousy. Journal of Personality, 51, 108-136. http://dx.doi.org/10.1111/j.1467-6494.1983.tb00857.x

Pines, A. M., \& Friedman, A. (1998). Gender differences in romantic jealousy. The Journal of Social Psychology, 138(1), 54-71. http://dx.doi.org/10.1080/00224549809600353

Raubenheim, J. (2004). An item selection procedure to maximise scale reliability and validity. SA Journal of Industrial Psychology, 30 (4), 59-64. http://dx.doi: 10.4102/sajip.v30i4.168

Schermelleh-Engel, K., \& Moosbrugger, H. (2003). Evaluating the fit of structural equation models: Tests of significance and descriptive goodness-of-fit measures. Methods of Psychological Research Online, 8(2), 23-74. 
Shackelford, T. K., \& Buss, D. M. (1997). Cues to infidelity. Personality and Social Psychology Bulletin, 23, 1034-1045. http://dx.doi.org/10.1177/01461672972310004

Shackelford, T. K., Voracek, M., Schmitt, D. P., Buss, D. M., Weekes-Shackelford, V. A., \& Michalski, R. L. (2004). Romantic jealousy in early adulthood and in later life. Human Nature, 15(3), 283-300. http://dx.doi.org/ 10.1007/s12110-004-1010-Z

Sharpsteen, D. J. (1991). The organization of jealousy knowledge: Romantic jealousy as a blended emotion. In P. Salovey (Ed.), The psychology of jealousy and envy (pp. 31-48). New York, NY: Guilford Press.

Speed, A., \& Gangstead, S. W. (1997). Romantic popularity and mate preferences: A peernomination study. Personality and Social Psychology Bulletin, 23(9), 928-936. http://dx.doi.org/ 10.1177/0146167297239002

Stevens, J. (2009). Applied multivariate statistics for the social sciences. New York, NY: Routledge Taylor \& Francis Group.

Tabachnick, B. G., \& Fidell, L. S. (2007). Using multivariate statistics. Boston, MA: Pearson, Allyn \& Bacon.

Timmerman, L. M. (2001). Jealousy expression in long-distance romantic relationships (Doctoral dissertation). Available from ProOuest Dissertations and Theses database. (UMI No. 3008459)

Varga, C. M., Gee, C. B., \& Munro, G. (2011). The effects of sample characteristics and experience with infidelity on romantic jealousy. Sex Roles, 65, 854-866. http://dx.doi.org/10.1007/s11199011-0048-8

Warber, K. M. (2007). The impact of sex and gender in the relationships among attachment, romantic jealousy, and varying forms of aggression in adult romantic jealousy (Doctoral dissertation). Available from ProOuest Dissertations and Theses database. (UMI No. 3272857)

Ward, J., \& Voracek, M. (2004). Evolutionary and social cognitive explanations of sex in romantic jealousy. Australian Journal of Psychology, 56(3), 165-171. http://dx.doi.org/10.1080/000495 30412331283381

White, G. L. (1981). Some correlates of romantic jealousy. Journal of Personality, 49(2), 129-147. http://dx.doi.org/10.1111/j.1467-6494.1981.tb00733.x

Wreen, M. J. (1989). Jealousy. Nous, 23(5), 635-652. 